\title{
Coğrafi işaretli Alanya avokadosu ile yoğurt üretimi ve bazı özelliklerinin araştırılması
}

\section{Investigating some properties of yogurt produced using Alanya avocado with geographical indication}

\author{
Manolya Eser ÖNER ${ }^{1}$, Aslı TARHAN ${ }^{2}$, Mehmet Durdu ÖNER ${ }^{2}$ († \\ ${ }^{1}$ Alanya Alaaddin Keykubat Üniversitesi, Mühendislik Fakültesi, Gıda Mühendisliği Bölümü, Alanya, Antalya \\ ${ }^{2}$ Alanya Hamdullah Emin Paşa Üniversitesi, Sanat ve Tasarım Fakültesi, Gastronomi ve Mutfak Sanatları Bölümü, Alanya, Antalya \\ Sorumlu yazar (Corresponding author): M. E. Öner, e-posta (e-mail): manolya.oner@alanya.edu.tr \\ Yazar(lar) e-posta (Author e-mail): asli.tarhan94@hotmail.com, mehmetdurduoner55@gmail.com
}

\section{MAKALE BİLGİSİ}

Alınış tarihi 17 Mart 2020

Düzeltilme tarihi 01 Haziran 2020

Kabul tarihi 02 Haziran 2020

\section{Anahtar Kelimeler:}

Avokado

Yoğurt

Fermantasyon

Serum ayrilması

Duyusal analiz

\begin{abstract}
ÖZ
$\mathrm{Bu}$ çalışmada coğrafi işaretli Alanya avokadosu eklenerek (\%0, \%6, \%10 ve \%15) üretilen yoğurt örneklerinin $\mathrm{pH}$, kuru madde, serum ayrılması, titrasyon asitliği, su tutma kapasitesi, renk değerleri ve duyusal özellikleri incelenmiştir. Avokado içerisindeki besin öğelerinin yoğurt kültürlerini sitümüle etmesi sebebi ile avokadolu yoğurt örneklerinin $\mathrm{pH}$ değerinde düşme ve titrasyon asitliğinde yükselme belirlenmiştir. Avokado oranı arttıkça su tutma kapasitesinde artma ve serum ayrılmasında azalma meydana gelmiştir. Renk değerleri incelendiğinde avokado oranı arttıkça $L^{*}$ değerinde azalma, $b^{*}$ ve $\Delta E^{*}$ değerlerinde artma gözlemlenirken, a* değerinde değişim belirlenmemiştir. Yedi gün $4 \pm 1^{\circ} \mathrm{C}^{\prime}$ de saklanan örneklerde yeşil renk azalmıştır. Duyusal analiz sonuçlarına göre en çok ve en az beğenilen ürünler sırası ile $\% 6$ ve $\% 15$ oranındaki avokadolu yoğurtlar olmuştur. Alanya avokadosu ile üretilen yoğurt mevcut yoğurt ürünlerine alternatif olabilecek potansiyele sahiptir.
\end{abstract}

\section{ARTICLE INFO}

Received 17 March 2020

Received in revised form 01 June 2020

Accepted 02 June 2020

\section{Keywords:}

Avocado

Yogurt

Fermentation

Serum separation

Sensory analysis

\begin{abstract}
In this study, $\mathrm{pH}$, dry matter, serum separation, titratable acidity, water holding capacity, color values and sensory attributes of yogurt produced using different ratios $(0,6,10$, and $15 \%)$ of Alanya avocado with geographical indication were investigated. There was a decrease in $\mathrm{pH}$ and increase in titratable acidity of avocado yogurt samples due to stimulation of yogurt cultures by avocado nutrients. Increase in avocado ratio, increased water holding capacity and decreased serum separation in samples. In color values, $\mathrm{L}^{*}$ value decreased, $\mathrm{b}^{*}$ and $\Delta \mathrm{E}^{*}$ values increased while $\mathrm{a}^{*}$ value remained constant with increasing avocado ratio. After seven days of storage at $4 \pm 1^{\circ} \mathrm{C}$, there was a decrease in greenness of samples. According to the sensory analysis, $6 \%$ was the most, whereas $\% 15$ was the least liked avocado yogurt. Yogurt made with Alanya avocado has a potential to be an alternative to existing yogurt products.
\end{abstract}

\section{Giriş}

Avokado (Persea americana Mill.) Lauraceae ailesinden gelen, kökeni Orta Amerika'ya dayanan, yarı tropik ve tropik iklim şartlarına göre yetişen binlerce yıllık bir meyvedir (Gölükçü 2006). Türkçe adı Amerikan armudu olmasına rağmen yaygın olarak kullanılan adı avokadodur. Kendine has tadı ve aroması olan avokado, yüksek miktarda A, B, C, E ve K vitaminleri, fosfor, magnezyum, demir, potasyum, kalsiyum, çinko gibi mineraller ve tekli doymamış yağ asitlerini içerir (Bayram 2013). Avokadoyu üreten başlıca ülkeler Meksika, Şili, ABD, Avustralya, Güney Afrika, Peru, Endonezya ve İsrail'dir. Dünya üretiminde en büyük pay 1.83 milyon ton ile Meksika'ya aittir (FAO 2019). Türkiye'de iklim şartlarının uygun olduğu illerden Antalya (\%75-80), Mersin (\%15-20), Muğla ve Hatay'da (\%2-5) avokado yetiştirilmektedir (Bayram 2012). Ayrıca Antalya ilinin Alanya ve Gazipaşa ilçelerinde yetiştirilen Fuerte çeşidi avokado coğrafi işaretli olarak tescil edilmiş ve Alanya avokadosu olarak isimlendirilmiştir (TURKPATENT 2018). Yıllık avokado üretimi 1997 y1lından 2018 yılına 225 tondan 3164 tona ulaşarak 14 kat artış göstermiştir (TUİK 2018). Bu meyvenin tanınması ve kullanım alanlarının çoğalması ile üretim ve tüketim potansiyeli olumlu yönde değişim göstermiştir. 
Avokado tüketimi sağlıklı beslenme açısından önemli bir yer tutmaktadır. İyi kolesterol (HDL) seviyesini yükseltmesi ve metabolik sendromu azaltması gibi olumlu etkileri bilinmektedir (Fulgoni ve ark. 2013). Ayrıca içeriğindeki yüksek miktarda potasyum ve düşük miktarda sodyum kalp hastalıklarına karşı koruyucu etki göstermektedir (Alvarez ve ark. 2012). Türkiye'de avokado meyvesi genellikle taze olarak tüketilmektedir. Ancak ABD ve Meksika gibi avokadonun çok tüketildiği ülkelerde püre halinde kullanımı yüksektir. Bu sebeple farklı gıda işleme teknolojileri ile avokado püresinin raf ömrünü uzatma, vitamin ve antioksidan değerlerini koruma ve renk kaybını önlemek amacıyla çalışmalar yapılmıştır (JacoboVelazquez ve Hernandez-Brenes 2010; Quevedo ve ark. 2011; Fernandes ve ark. 2016). Ayrıca, avokado kullanılarak üretilen çay, şarap, sirke ve meyve suyu gibi patentli gıda ürünleri de bulunmaktadır (Araújo ve ark. 2018).

Yoğurt, Lactobacillus delbrueckii subsp. bulgaricus ve Streptococcus thermophilus yoğurt kültürlerinin laktik asit fermantasyonu ile oluşan koagule süt ürünüdür. Fermantasyon sırasında üretilen laktik asit ile sütün $\mathrm{pH}$ değeri 6.3-6.5'ten 4.6 seviyesine düşmektedir, böylece yoğurda özgü karakteristik özelliklerden tat, koku ve koyu kıvam ortaya çıkmaktadır (Köse ve Ocak 2014). Beslenme değeri bakımından yoğurt süte benzer özellikte olup, içeriğindeki mineral ve vitaminlerin biyolojik yarayışlılığıda yüksektir (Özer 2006). Son yıllarda tüketicinin beklentilerini karşılamak için sade yoğurda alternatif olarak kurutulmuş, tütsülenmiş, konsantre, dondurulmuş ve meyve ile tatlandırılmış yoğurt ürünleri üretilmeye başlanmıştır. Dünya genelinde yoğurt çeşitleri arasında en çok ilgi çeken meyveli yoğurttur. Çeşitli meyve püreleri ile zenginleştirilip, formüller geliştirilerek yeni yoğurt ürünleri üretilmektedir. Böylece hem meyvede hem yoğurtta bulunan besin öğelerinden faydalanılmakta olup, yeni fonksiyonel ürünler ortaya çıkmaktadır (Peker 2012).

$\mathrm{Bu}$ çalıșmanın amacı \%0, \%6, \%10 ve \%15 (mL mL $\left.\mathrm{mL}^{-1}\right)$ Alanya avokadosu eklenerek üretilen yoğurdun fizikokimyasal ve duyusal özelliklerini belirlemektir.

\section{Materyal ve Yöntem}

\subsection{Avokadolu yoğurt üretimi}

Yerel bir işletmeden (Alanya, Antalya, Türkiye, 2018) sağlanan çiğ inek sütüne $90^{\circ} \mathrm{C}$ 'de $5 \mathrm{dk}$ sıcaklık sensörlü manyetik karıştırıcıda (IKA C-MAG HS 7, Staufen, Germany) 1sıl işlem uygulanmış ve daha sonra $42^{\circ} \mathrm{C}^{\prime}$ ye kadar buz banyosunda soğutulmuştur (Weerathilake ve ark. 2014). Fuerte türü olan Alanya avokadosu üreticiden (Alanya, Antalya, Türkiye) Kasım 2018 döneminde temin edilip, istenilen tekstür için 5 gün oda sıcaklığında $\left(25^{\circ} \mathrm{C}\right)$ olgunlaştırılmıştır. Kabukları soyulup, çekirdekleri çıkarıldıktan sonra püre haline getirilen $100 \mathrm{~mL}$ avokado $300 \mathrm{~mL}$ süt ile (Waring 8011S Lab Blender, Winsted, USA) karıştırıcıda $1 \mathrm{dk}$ sürede karışım haline getirilmiştir. Ayrıca, Chr-Hansen (Hoersholm, Danimarka) firmasından temin edilen Yoflex Thermophilic (YF-L812 50U) Freeze-dried Lactic Culture for Direct Vat Set (DVS) $100 \mathrm{~mL}$ sütün içerisine $0.2 \mathrm{~g}$ çözündürülerek yoğurt kültürü hazırlanmıştır.

Avokadolu yoğurt yapımı için hazırlanan avokado-süt karışımı $42^{\circ} \mathrm{C}^{\prime}$ deki süte $\% 0, \% 6, \% 10$ ve $\% 15\left(\mathrm{~mL} \mathrm{~mL}^{-1}\right)$ avokado oranlarını elde etmek üzere ilave edilmiştir. Ardından $10 \mathrm{~mL}$ yoğurt kültürü, $240 \mathrm{~mL}$ 'lik her bir avokado-süt karışımına eklenerek manyetik karıştırıcıda (IKA C-MAG HS7,
Almanya) $600 \mathrm{rpm} 5 \mathrm{dk}$ karıştırılıp, plastik kaplara $(250 \mathrm{~mL})$ ambalajlanarak etüvde (Memmert, Almanya) $42^{\circ} \mathrm{C}^{\prime} \mathrm{de} \mathrm{pH}$ değeri 4.5'e ulaşana kadar $\left(\begin{array}{lll}\sim 5 & \text { sa }\end{array}\right)$ inkübe edilmiştir. Inkübasyon süresinde her saat $\mathrm{pH}$ ölçümü yapılmıştır. Avokadolu yoğurt örnekleri analizler öncesinde $4 \pm 1^{\circ} \mathrm{C}^{\prime} \mathrm{de} 24 \mathrm{sa}$ bekletilmiştir.

\section{2. $p H$ tayini}

Homojenize edilmiş $10 \mathrm{~mL}$ yoğurt örnekleri deney tüpüne alınmış ve pH metre (Seven Excellence, Mettler Toledo, Çin) ile $\mathrm{pH}$ değerleri ölçülmüştür.

\subsection{Toplam kuru madde tayini}

Darası alınan petrilere $1 \mathrm{~g}$ örnek tartılmış, ağırlık sabitleninceye kadar $105^{\circ} \mathrm{C}$ etüvde (Memmert UF 110, Almanya) bekletilmiştir. Daha sonra petri ve kuru numunenin ağırlığ1 ölçülmüş, toplam kuru madde oranı $\left(\mathrm{g} \mathrm{g}^{-1}\right)$ yüzde cinsinden hesaplanmıştır (AOAC 1997).

\subsection{Serum ayrlması analizi}

Üzerine filtre kağıdı yerleştirilmiş huniye $25 \mathrm{~g}$ yoğurt numunesi eklenmiştir. Daha sonra $4 \pm 1^{\circ} \mathrm{C}$ 'de 2 sa bekletilip huninin altındaki erlene süzülen serum miktarı tartılarak sonuç \% olarak hesaplanmıştır (Konar 1980).

\subsection{Titrasyon asitliği tayini}

Titrasyon asitliği değeri, fenolftalein indikatörü ve $0.1 \mathrm{~N}$ $\mathrm{NaOH}$ çözeltisi kullanılarak \% laktik asit olarak belirlenmiştir (TS 2002 ve TS 2006).

\subsection{Su tutma kapasitesi}

Su tutma kapasitesi (STK) belirlemek için darası bilinen santrifüj tüplerine $10 \mathrm{~g}$ avokadolu yoğurt ürünü tartılmış ve $5000 \mathrm{xg}$ 'de $4^{\circ} \mathrm{C}$ 'de $20 \mathrm{dk}$ santrifüj edilmiştir (SIGMA, D-37520 Osterde am Harz, Almanya). Süpernatant uzaklaştırılıp, sediment ağırlığ hesaplanmıştır (Bakırc1 2014).

\subsection{Renk tayini}

Avokadonun iç ve dış kısmı ve son ürün olan avokadolu yoğurtların farklı üç noktasından iki tekrar şeklinde renk tayini cihazı (Konica Minolta Chroma Meter CR-5, Konica Minolta Optics Inc., Japonya) ile ölçüm yapılmış, L* (açıklık-koyuluk), $\mathrm{a}^{*}$ (yeşillik-kırmızılık), b* (sarılık-mavilik) ve $\Delta \mathrm{E}^{*}$ (toplam renk farkı beyaz standart kalibrasyon plakası referans alınarak) değerleri belirlenmiştir (Köse ve Şahinbaşkan 2008).

\subsection{Duyusal analiz}

Duyusal analiz puanlama testi ile ürünlerin renk, koku, kaşıkta kıvam, ağızda kıvam, homojen yapı, yabancı lezzet, tat, ekşi tat, ağızda kalan tat, yağlılık hissi ve genel beğeni 5 (çok iyi) - 4 (iyi) - 3 (normal) - 2 (kötü) - 1 (çok kötü) olarak değerlendirilmiştir (Altuğ Onoğur ve Elmaci 2015). Siralama testinde ise en çok beğenilen üründen en az beğenilene doğru ürünler arasında sıralama yapılmıştır. Duyusal analize panelist olarak üniversitemizin lisans ve yüksek lisans öğrencileri, akademik ve idari personelinden oluşan 27 kişi katılmıştır. Panelistlere duyusal analiz öncesinde üründe aranan özellikler ile ilgili eğitim verilmiştir (Oner ve Wall 2012). Avokadolu yoğurtlar $(\% 0, \% 6, \% 10$ ve \%15) bir gün önceden hazırlanarak 
$4 \pm 1^{\circ} \mathrm{C}$ 'de saklanmış, duyusal analiz sırasında kapalı beyaz plastik kaplar içerisinde panelistlere servis edilmiştir.

\subsection{Istatistiksel analiz}

Analiz sonuçları ortalama \pm standart sapma olarak gösterilmiştir. Deneyler iki kez tekrarlanmıştır. SPSS (Statistics 22.0, New York, USA) paket programı ile \%95 güven aralığında tek yönlü varyans analizi (ANOVA) yapılmıştır (Oner ve Walker 2011). Ürünler arasındaki farklılığı belirlemek için Duncan çoklu sıralama testi (Duncan's Multiple Range Test) uygulanmıştır.

\section{Bulgular ve Tartışma}

\subsection{Fizikokimyasal özellikler}

Avokadolu yoğurt üretiminde kullanılan çiğ sütün $\mathrm{pH}$ değeri 6.31, titrasyon asitliği $\% 0.2$, toplam kuru madde oran1 $\% 12.68$ olarak belirlenmiştir. Benzer değerler diğer çalışmalarda da gözlemlenmiştir (Akın ve ark. 2016; Beykaya ve ark. 2017). Avokado meyvesinin türüne, yetiştirildiği bölgedeki iklim şartlarına, hasat zamanına ve jeolojik yapısına bağlı olarak fiziksel ve kimyasal özelliklerinde farklılıklar gözlemlenmektedir (Gölükçü 2006). Bu çalışmada kullanılan Fuerte çeşidi olan Alanya avokadosunun pH değeri 6.95 ve toplam kuru madde oranı \%28.04'tür. Ayrıca avokadonun iç kısmının sarı $L^{*}:$ 69.09, a*: $-6.20, b^{*}: 31.09, \Delta E^{*}: 36.69$, diş kısmının da yeşile yakın $L^{*}: 47.90, a^{*}:-15.50, b^{*}: 25.82, \Delta E^{*}$ : 52.70 olduğu belirlenmiştir.

Gıdaların işlenme aşamalarındaki pH ölçümü özellikle denatüre olmuş yiyeceklerin enzimatik aktiviteleri, mikroorganizmaların büyüme ve bakteriyel oluşumu ve kimyasal reaksiyonların dikkatli bir şekilde izlenmesi için gereklidir (Andrés-Bello ve ark. 2013). Şekil 1'de avokadolu yoğurt örneklerinin fermantasyon sürecindeki $\mathrm{pH}$ değişimi gösterilmiştir. Fermantasyon başlangıcında $\mathrm{pH}$ değerleri 6.25 (\%0 kontrol yoğurt) ile 6.49 (\%15 avokadolu yoğurt) belirlenirken $4.5-5$ saat fermantasyon süresi sonunda bütün örneklerin yaklaşık pH değeri 4.5 ölçülmüş, örneklerdeki avokado oranlarının $\mathrm{pH}$ üzerine etkisi istatistiksel olarak anlamlı bulunmamıştır ( $\mathrm{p}>0.05)$. Farklı oranlardaki avokadolu yoğurtların $4 \pm 1{ }^{\circ} \mathrm{C}$ 'de $24,48,72$ sa depolama sürecindeki $\mathrm{pH}$ değişimi Şekil 2'de gösterilmiştir.

Fermantasyon sonrası avokadolu yoğurt örneklerinin depolama sıcaklığ $15^{\circ} \mathrm{C}$ 'nin altında olduğundan, starter mikroorganizmaların metabolik faaliyetleri ve dolayısıyla asitlik gelişimi çok yavaşlamış (Yaygın 1999), pH değişimi gözlemlenmemiştir $(p>0.05)$. Ancak avokado içerisindeki besin öğelerinin (suda çözünen vitaminler gibi) yoğurt kültürlerini stimüle edip laktik asit üretimini hızlandırması sebebi ile (Özer 2006) avokadolu yoğurtların $\mathrm{pH}$ değerinde kontrol yoğurda göre düşüş belirlenmiştir $(\mathrm{p} \leq 0.05)$. G1dalardaki toplam asit konsantrasyonunu belirleyen titrasyon asitliği, avokadolu yoğurt örnekleri için değerlendirildiğinde $\mathrm{pH}$ değerlerine benzer sonuç gözlemlenmiştir (Şekil 3). Örneklerdeki avokado oranı arttıkça titrasyon asitliğinde artış belirlenmiştir, ancak avokado ilavesi ile Türk Gıda Kodeksi Ferment Süt Ürünleri Tebliği’ne göre yoğurt titrasyon asitliği sınırı aşılmamıştır (\% laktik asit cinsinden 0.6-1.5) (TGK 2009) ve örneklerin titrasyon asitlik değerleri \%0.94 ile \%1.15 arasında belirlenmiştir.

Yoğurt ürünlerinde fiziksel ve duyusal nitelikler tüketici beğenisi açısından önemlidir. Yoğurt pıhtısında sıkı olmayan yap1 ve serum ayrılması başlıca tekstürel sorunlar arasında yer alır. Geleneksel 1sıl işlem ve homojenizasyon yöntemi ile üretilen yoğurtlarda bu sorunlar azalmıştır (Özer 2006). Ayrıca alternatif olarak 1sıl olmayan ultrason teknolojisi geleneksel yöntemlerle kıyaslandığında yoğurt ve ayran gibi fermente süt ürünlerinin viskozite ve STK'sında artma gözlemlenmiştir (Şengül ve ark. 2009). Şekil 3'te gösterildiği gibi yaptığımız bu çalışmada, avokadonun örneklerde STK'yı artırdığı belirlenmiş, avokado içermeyen sade yoğurt örneğinde en düşük STK $(\% 64.83)$ ortaya çıkmıştır $(\mathrm{p} \leq 0.05)$. Ancak $\% 6$ ve $\% 10$ oranlarındaki avokadolu yoğurt örneklerinde STK değerleri arasındaki fark anlamlı bulunmamıştır $(\mathrm{p}>0.05)$. Sonuç olarak serum ayrılması avokado oranı arttıkça azalmıştır $(\mathrm{p} \leq 0.05)$. Bunun sebebi olarak diyet lifi oranı $(\sim \% 28)$ yüksek olan avokadonun örnekteki suyu bağlaması olarak düşünülmektedir (Christous ve ark. 2009). Yapılan bir çalışmada, farklı meyve ve baharatlar kullanarak üretilen sürülebilir yoğurt örneklerinde en düşük STK yaban mersinli en yüksek ise balkabaklı yoğurtta belirlenmiştir (Gürlin 2013). Böylece avokado içeriğindeki yüksek miktardaki doğal şekerin suyu bağlayıcı özelliğinden viskoziteyi artırdığı gözlemlenmiştir (Goff ve Richard 2013).

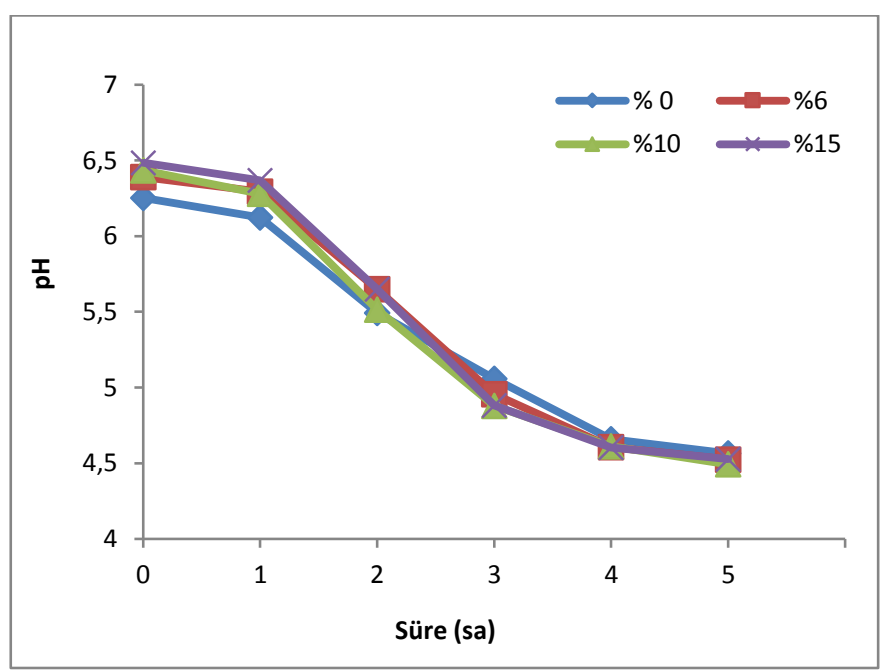

Şekil 1. Yüzde $0,6,10$ ve 15 oranında avokado içeren yoğurtların fermantasyon sürecindeki pH değişimi. Figure 1. Change in $\mathrm{pH}$ values of $0,6,10$ and $15 \%$ avocado yogurt samples during fermentation process. 


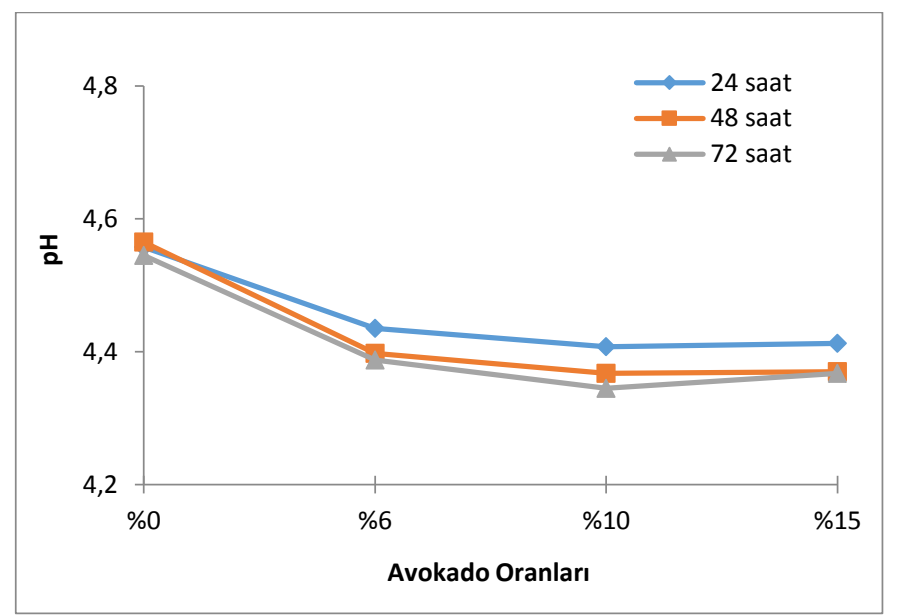

Şekil 2. Avokadolu yoğurtların depolama sürecindeki pH değişimi (24, 48, $72 \mathrm{sa})$.

Figure 2. Change in $\mathrm{pH}$ values of avocado yogurt samples during storage time $(24,48,72 \mathrm{~h})$.
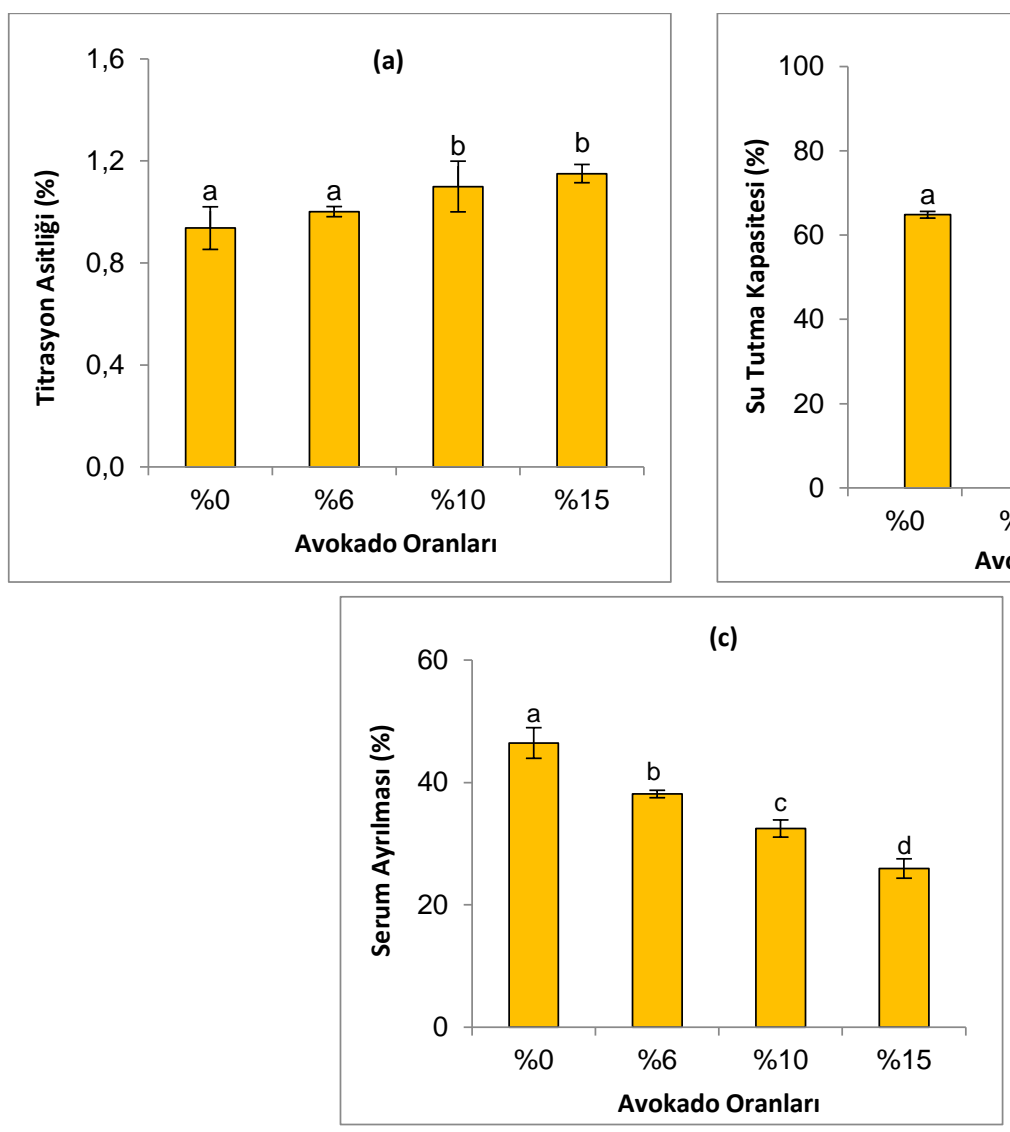

Şekil 3. Avokadolu yoğurt ürünlerinin (a) titrasyon asitliği, (b) STK ve (c) serum ayrılması değerleri.

Figure 3. (a) Titratable acidity, (b) water holding capacity, and (c) serum separation values of avocado yogurt samples.

Gıdalarda renk ürün kalitesinin belirlenmesinde önemli parametrelerden biridir. Avokadolu yoğurtların $4 \pm 1^{\circ} \mathrm{C}$ ' de 1 ve 7 gün saklama sonrasında belirlenen renk değerleri $\left(\mathrm{L}^{*}, \mathrm{a}^{*}, \mathrm{~b}^{*}\right.$, $\left.\Delta \mathrm{E}^{*}\right)$ Çizelge 1'de gösterilmiştir. Avokado içermeyen kontrol örneğinin $(\% 0)$ renk değerlerinde saklama süresince değişim gözlenmemiş, ancak $b^{*}$ değerinde dolayısıyla sarımsı renkte artış belirlenmiştir. Örneklerin renk değerleri incelendiğinde avokado oranı arttıkça $L^{*}$ değerinde azalma $(p \leq 0.05), b^{*}$ değerinde artma $(\mathrm{p} \leq 0.05)$ ve toplam renk farkında artma gözlemlenirken $\quad(\mathrm{p} \leq 0.05), \quad \mathrm{a}^{*} \quad$ değerinde değişim belirlenmemiştir $(\mathrm{p}>0.05)$. Dolayısıyla avokado oranından kaynaklanan koyulaşma ve sarımsı renk artışı olurken yeşil renkte değişim olmamıştır. Yedi gün süreyle $4 \pm 1^{\circ} \mathrm{C}$ 'de saklanan örneklerde de benzer sonuçlar ortaya çıkmış ancak a* değerinde azalma dolayısıyla yeşil renkte azalma belirlenmiştir. Bu değişimin avokadolu yoğurt örneklerindeki avokadonun enzimatik kahverengileşmesinden (Fennema 1996) ve klorofil degradasyonundan (Koca ve ark. 2007) kaynaklandiğı düşünülmektedir. Meyve ve türevi ürünlerin ilave edildiği 
yoğurtlarda benzer renk değişimleri gözlemlenmiştir (Temiz ve ark. 2014).

\subsection{Duyusal Özellikler}

Puanlama ve siralama testi uygulanarak elde edilen duyusal analiz verileri ile değişik oranlarda avokado eklenmesinin tüketici algısına etkisi belirlenmiştir. Şekil 4'te gösterildiği gibi genel beğeni verilerine göre en çok beğenilen örnek \%6 avokadolu yoğurt olup, bu örnek ile $\% 0$ kontrol ve \%10 avokadolu yoğurt örnekleri arasında istatistiksel bir fark bulunmamıştır ( $p>0.05)$. Ancak \%15 avokadolu yoğurt diğer örneklerle kıyaslandığında en az beğenilmiştir $(\mathrm{p} \leq 0.05)$. Renk bir ürünün kabul edilebilirliğini belirleyen önemli bir parametredir. Puanlama testi sonuçlarına göre renk değeri $\% 6$ ile $\% 10$ oranında avokado içeren örneklerde $\% 15$ avokado içeren örneğe göre daha yüksek belirlenmiştir. Yeşil renkteki yoğunluk panelistlerin beğenisini azaltmıştır. Örnekler koku bakımından değerlendirildiğinde ise $\% 6$ ve $\% 10$ oranlı örnekler ile kontrol örneği arasında fark anlamlı bulunmamıştır ( $p>0.05)$, ancak \%15 avokadolu örnek en düşük puanı almıştır ( $p>0.05)$.

Avokado oranı arttıkça STK artmış, serum ayrılması azalmıştır. Bu sonuçlara bağlı olarak ağızda kıvam, kaşıkta kıvam ve homojen yap1 bakımından örnekler değerlendirildiğinde $\% 6$ ve $\% 10$ avokadolu yoğurtlar, avokado içermeyen kontrol yoğurda göre daha yüksek puan almıştır. $\% 15$ avokadolu yoğurt, alışılmışın dışındaki fazla kıvamı ve homojen yapısından dolayı beğenilmemiştir. Tat, ekşi tat, yağlılık hissi ve ağızda kalan tat yönünden avokado içermeyen kontrol yoğurt ile $\% 6$ ve $\% 10$ avokadolu örnekler arasındaki fark istatistiksel olarak anlamlı bulunmamıştır ( $p>0.05)$. Avokadolu yoğurt örneklerine uygulanan siralama testine göre örnekler en çok beğenilenden en az beğenilene $\% 6, \% 0, \% 10$, $\% 15$ olarak sıralanmaktadır.

Çizelge 1. Avokadolu yoğurtların 1 ve 7 gün $4 \pm 1^{\circ} \mathrm{C}$ 'de saklama sonrası renk değerleri.

Table 1. Color values of avocado yogurt samples after 1 and 7 days of storage at $4 \pm 1^{\circ} \mathrm{C}$.

\begin{tabular}{|c|c|c|c|c|c|}
\hline Saklama Süresi (Gün) & Avokado Oranı (\%) & $\mathrm{L}^{*}$ & $a^{*}$ & $\mathrm{~b}^{*}$ & $\Delta \mathrm{E}^{*}$ \\
\hline 1 & 0 & $81.01 \pm 0.83^{\mathrm{dZ}}$ & $-5.01 \pm 0.34^{\mathrm{b}}$ & $5.72 \pm 1.09^{\mathrm{a}}$ & $13.55 \pm 0.58^{\mathrm{a}}$ \\
\hline 1 & 6 & $77.94 \pm 0.42^{\mathrm{c}}$ & $-6.90 \pm 0.06^{\mathrm{a}}$ & $13.99 \pm 0.81^{\mathrm{b}}$ & $19.52 \pm 0.04^{b}$ \\
\hline 1 & 10 & $76.34 \pm 0.09^{b}$ & $-7.02 \pm 0.21^{\mathrm{a}}$ & $16.49 \pm 0.07^{\mathrm{c}}$ & $22.10 \pm 0.17^{\mathrm{c}}$ \\
\hline 1 & 15 & $73.83 \pm 0.13^{\mathrm{a}}$ & $-6.78 \pm 0.21^{\mathrm{a}}$ & $19.00 \pm 0.16^{\mathrm{d}}$ & $25.41 \pm 0.04^{\mathrm{d}}$ \\
\hline 7 & 0 & $81.09 \pm 0.21^{\mathrm{d}}$ & $-5.41 \pm 0.24^{\mathrm{b}}$ & $7.38 \pm 0.49^{\mathrm{a}}$ & $13.85 \pm 0.40^{\mathrm{a}}$ \\
\hline 7 & 6 & $75.83 \pm 0.10^{\mathrm{b}}$ & $-5.93 \pm 0.01^{\mathrm{a}}$ & $14.86 \pm 0.75^{\mathrm{b}}$ & $21.36 \pm 0.45^{\mathrm{b}}$ \\
\hline 7 & 10 & $71.07 \pm 0.27^{\mathrm{c}}$ & $-5.09 \pm 0.01^{\mathrm{c}}$ & $16.93 \pm 0.01^{\mathrm{c}}$ & $26.21 \pm 0.23^{c}$ \\
\hline 7 & 15 & $66.91 \pm 0.73^{\mathrm{a}}$ & $-4.23 \pm 0.03^{\mathrm{d}}$ & $19.04 \pm 0.30^{\mathrm{d}}$ & $30.69 \pm 0.78^{d}$ \\
\hline
\end{tabular}

${ }^{\mathrm{z}} \mathrm{Ayn}$ sütun ve aynı saklama süresi içerisinde belirtilen ortalama \pm standart sapma değerlerinde kullanılan farklı harfler istatistiksel olarak farklıdır ( $\leq 0.05$ ).

${ }^{\mathrm{z}}$ Values, indicated with mean \pm standard deviation, in the same column and same storage day followed by different letters significantly different ( $\mathrm{p} \leq 0.05$ ).

\%0 Avokadolu Yoğurt

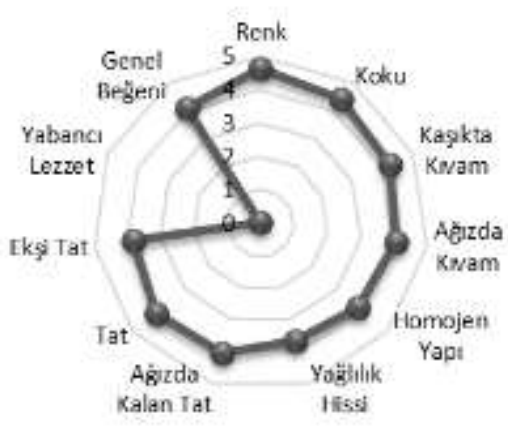

\%10 Avokadolu Yoğurt

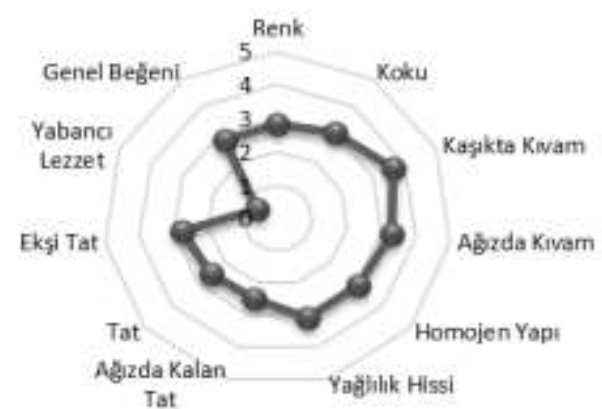

\%6 Avokadolu Yoğurt

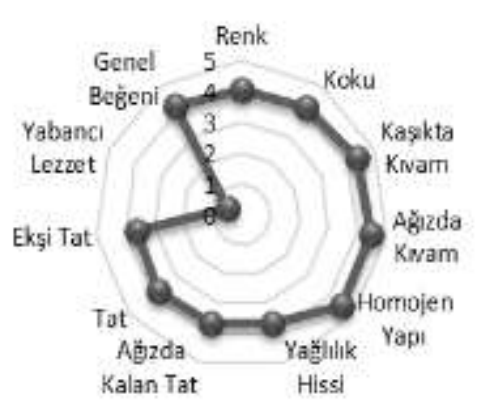

\%15 Avokadolu Yoğurt

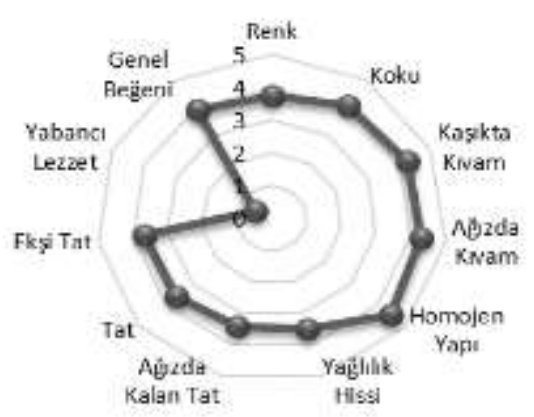

Şekil 4. Farklı oranlarda avokado içeren yoğurt ürünlerine uygulanan duyusal analiz puanlama testi.

Figure 4. Sensory evaluation hedonic scale rating test for different ratios of avocado yogurt samples. 


\section{Sonuç}

Avokadolu yoğurt örneklerinde avokado oranı arttıkça $\mathrm{pH}$ değerlerinde azalma, titrasyon asitliğinde artma gözlemlenmiştir. Avokado oranındaki artışın STK'yı artırdığ ve buna bağlı olarak serum ayrılmasını azalttığı belirlenmiştir. Yapılan duyusal analiz sonuçlarına göre \%6 oranındaki avokadolu yoğurt en çok beğeni almıştır. Bir hafta süreyle $4 \pm 1{ }^{\circ} \mathrm{C}$ 'de saklanan avokadolu yoğurtlarda yeşil renkte azalma belirlenmiştir. Sonuç olarak coğrafi işaretli Alanya avokadosu ile üretilen yoğurt katma değerli gıda ürünleri arasında yer alma potansiyeline sahiptir.

\section{Teşekkür}

$\mathrm{Bu}$ makale Aslı Tarhan'ın Avokadolu Yoğurt Üretimi başlıklı yüksek lisans tezinden üretilmiştir.

\section{Kaynaklar}

Akın MS, Yapık Ö, Akın MB (2016) Adıyaman ilinde süt üretim çiftliklerinden ve toplayıcılardan sağlanan sütlerin bazı özellikleri. Harran Tarım ve Gıda Bilimleri Dergisi 20(4): 253-265.

Altuğ Onoğur T, Elmacı Y (2015) Gıdalarda duyusal değerlendirme. Sidas Yayınları, İzmir.

Alvarez LD, Moreno AO, Ochoa FG (2012) Avocado. In tropical and subtropical fruits: Postharvest physiology, processing and packaging, Edited by M. Siddiq, Wiley-Blackwell, Oxford, England.

Andrés-Bello A, Barreto-Palacios V, García-Segovia P, Mir-Bel J, Martínez-Monzó J (2013) Effect of pH on color and texture of food products. Food Engineering Reviews 5(3): 158-170.

AOAC (Association of Official Analytical Chemists) (1997) International official methods of analysis. 16th Edition, Arlington, VA, USA.

Araújo RG, Rodriguez-Jasso RM, Ruiz HA, Pintado MME, Aguilar CN (2018) Avocado by-products: Nutritional and functional properties. Trends in Food Science and Technology 80: 51-60.

Bakırcı S (2014) Bal kabağı lifi kullanımının yarım yağlı yoğurdun kalitesi ve depolama stabilitesi üzerine etkisi. Yüksek Lisans Tezi, Fen Bilimleri Enstitüsü, Atatürk Üniversitesi, Erzurum.

Bayram S (2012) Avokado Yetiştiriciliği. Gıda, Tarım ve Hayvancılık Bakanlığı, Eğitim, Yayım ve Yayınlar Dairesi Başkanlığı, Çiftçi Eğitim Serisi, Ankara, Yayın No: 2012/47, s. 76.

Bayram S (2013) Bazı avokado çeşitlerinin anaçlık özelliklerinin ve üzerinde aşılı çeşitlerle uyuşma durumlarının incelenmesi. Doktora Tezi, Fen Bilimleri Enstitüsü, Süleyman Demirel Üniversitesi, Isparta.

Beykaya M, Özbey A, Yıldırım Z (2017) Sivas ilindeki bazı süt işletmelerine gelen sütlerin fiziksel, kimyasal ve mikrobiyolojik özelliklerinin belirlenmesi. Türk Tarım - Gıda Bilim ve Teknoloji Dergisi 5(4): 388-396.

Christous S, Dimitra L, Constantina T (2009) Enrichment of ice cream with dietary fibre: Effect of rheological properties, ice crystallization, and glass transition phenomena. Food Chemistry 115: 665-671.

FAO (2019) Food and agriculture organization of the United Nations. Agriculture

Database. https://apps.fas.usda.gov/newgainapi/api/Report/DownloadReportB yFileName?fileName=Avocado\%20Annual_Mexico\%20City_Mexi co_12-01-2019. Erişim 30 Mayıs 2020.

Fennema OR (1996) Food Chemistry. 3rd ed., CRC Press, Boca Raton, Florida, USA.

Fernandes FAN, Oliveira VS, Gomes WF, Rodrigues S (2016) Degradation kinetics of vitamin E during ultrasound application and the adjustment in avocado puree by tocopherol acetate addition. LWT-Food Science and Technology 69: 342-347.

Fulgoni VL, Dreher M, Davenport AJ (2013) Avocado consumption is associated with better diet quality and nutrient intake, and lower metabolic syndrome risk in US adults: results from the National Health and Nutrition Examination Survey (NHANES) 2001-2008. Nutrition Journal 12(1): 1-6.

Goff D, Richard WH (2013) Ice Cream. Springer, New York, USA.

Gölükçü M (2006) Bazı avokado (Persea americana Mill.) çeşitlerinin püre üretimine uygunluklarının belirlenmesi ve ürün stabilitesi üzerine depolama sıcaklığının etkisi. Doktora Tezi, Fen Bilimleri Enstitüsü, Akdeniz Üniversitesi, Antalya.

Gürlin E (2013) Sürülebilir nitelikleri yüksek meyveli ve baharatlı yoğurt üretimi. Yüksek Lisans Tezi, Fen Bilimleri Enstitüsü, Sakarya Üniversitesi, Sakarya.

Jacobo-Velazquez DA, Hernandez-Brenes C (2010) Biochemical changes during the storage of high hydrostatic pressure processed avocado paste. Journal of Food Science 75(6): 264-270.

Koca N, Karadeniz F, Burdurlu HS (2007) Effect of pH on chlorophyll degradation and colour loss in blanched green peas. Food Chemistry 100(2): 609-615.

Konar A (1980) İnek, keçi, koyun ve manda sütlerinin çeşitli sıcaklık derecelerinde ve değişik sürelerde işlenmelerin yoğurt kalitesine etkileri üzerinde araştırmalar. Doçentlik tezi, Ziraat Fakültesi Gıda Bilimi ve Teknolojisi Bölümü, Çukurova Üniversitesi, Adana.

Köse E, Şahinbaşkan T (2008) Renk yönetiminde kullanılan standart ICC profillerinin Türkiye'de oluşturulmuş bazı profiller ile karşılaştırılması. Politeknik Dergisi 11(4): 365-371.

Köse Ş, Ocak E (2014) Yoğurtta lezzet bileşenlerinin oluşumu ve bu oluşum üzerine etki eden faktörler. Akademik Gıda 12(2): 101-107.

Oner ME, Walker PN (2011) Effect of processing and packaging conditions on quality of refrigerated potato strips. Journal of Food Science 76(1): 35-40.

Oner ME, Wall MM (2012) Processing conditions for producing french fries from purple-fleshed sweet potatoes. Transactions of the American Society of Agricultural and Biological Engineers 55(6): 2285-2291.

Özer B (2006) Yoğurt bilimi ve teknolojisi. 1. baskı, Sidas Yayınları, İzmir.

Peker H (2012) Keçiboynuzu gamı kullanarak az yağlı yoğurt ve zeytin yaprağı ekstratı kullanılarak fonksiyonel meyveli yoğurt üretimlerinin araştırılması. Yüksek Lisans Tezi, Fen Bilimleri Enstitüsü, Pamukkale Üniversitesi, Denizli.

Quevedo R, Ronceros B, Garcia K, Lopéz P, Pedreschi F (2011) Enzymatic browning in sliced and puréed avocado: A fractal kinetic study. Journal of Food Engineering 105(2): 210-215.

Şengül M, Başlar M, Erkaya T, Ertugay MF (2009) Ultrasonik homojenizasyon işleminin yoğurdun su tutma kapasitesi üzerine etkisi. G1da 34(4): 219-222.

Temiz H, Tarakçı Z, İslam A (2014) Effect of cherry laurel marmalade on physicochemical and sensorial characteristics of the stirred yogurt during storage time. Gida 39(1): 1-8.

TGK (2009) Türk Gıda Kodeksi Fermente Süt Ürünleri Tebliği, Tebliğ No: $2009 / 25$. https://www.resmigazete.gov.tr/eskiler/2009/02/20090216-8.htm. Erişim 10 Ağustos 2019.

TS (Türk Standardı) (2002) Çiğ süt. TS 1018, Ankara.

TS (Türk Standardı) (2006) Yoğurt. TS 1330, Ankara.

TUİK (2018) Türkiye İstatistik Kurumu. Bitkisel üretim istatistikleri. http://www.tuik.gov.tr/PreTablo.do?alt_id=1001. Erişim 15 Eylül 2019.

TURKPATENT (2018) Alanya avokadosu. Tescil No: 386. Tescil $\begin{array}{cccc}\text { ettiren Alanya Ticaret ve Sanayi Odasi. } & \end{array}$ 
https://www.turkpatent.gov.tr/TURKPATENT/resources/temp/612 D385A-5046-418F-BAFE-E73E5D108530.pdf. Erişim 16 Ağustos 2019.

Weerathilake WADV, Rasika DMD, Ruwanmali JKU, Munasinghe MADD (2014) The evolution, processing, varieties and health benefits of yogurt. International Journal of Scientific and Research Publications 4(4): 1-10.

Yaygın H (1999) Yoğurt teknolojisi. Akdeniz Üniversitesi Basımevi, Antalya. 